W.G. Mills et al.

ODP Technical Note 33

\title{
HydROGEN SULFIDE DRILLING Contingency Plan ${ }^{1,2}$
}

\author{
William G. Mills, ${ }^{3}$ Mitchell J. Malone, ${ }^{3}$ and Karen Graber ${ }^{3}$
}

\section{OVERVIEW}

\section{Introduction}

This document guides personnel aboard the JOIDES Resolution in recognizing, preparing, and mitigating potentially dangerous hydrogen sulfide $\left(\mathrm{H}_{2} \mathrm{~S}\right)$ situations during drilling operations.

Not all situations can be foreseen on board the JOIDES Resolution, nor can detailed instructions be provided for every situation that might be encountered. The policies and guidelines set forth in this document should be considered as a minimum set of requirements for preparing and dealing with $\mathrm{H}_{2} \mathrm{~S}$ exposure.

In addition, these policies and guidelines can be used with other heavier-than-air toxic gases, provided that the proper gas detector systems have been installed and calibrated for the specific gas.

\section{Scope}

This document supersedes and replaces the two previous Ocean Drilling Program (ODP) $\mathrm{H}_{2} \mathrm{~S}$ safety documents, Technical Note 16 (Howard and Reudelhuber, 1991) and Technical Note 19 (Foss and Julson, 1993). This Technical Note is intended to supplement existing ODP and ship operator safety documents.

This document includes information about the following:

- Identifying, classifying, and responding to different levels of $\mathrm{H}_{2} \mathrm{~S}$ hazard;

- Preparing to core $\mathrm{H}_{2} \mathrm{~S}$-bearing formations;

${ }^{1}$ Mills, W.G., Malone, M.J., and Graber, K., 2006. Hydrogen sulfide drilling contingency plan. ODP Tech. Note, 33 [Online]. Available from World Wide Web: <http://wwwodp.tamu.edu/publications/tnotes/ tn33/INDEX.HTM>. [Cited YYYY-MMDD]

${ }^{2}$ See Disclaimer.

${ }^{3}$ Integrated Ocean Drilling Program, Texas A\&M University, 1000 Discovery Drive, College Station TX 77845-9547, USA. Correspondence author: mills@iodp.tamu.edu 
W.G. MILLS ET AL.

- Processing $\mathrm{H}_{2} \mathrm{~S}$-bearing cores;

- Setting up the fixed $\mathrm{H}_{2} \mathrm{~S}$ detection system;

- $\mathrm{H}_{2} \mathrm{~S}$ safety training, drills, and record keeping;

- Responsibilities and duties of personnel in regard to the policies set forth in this document;

- Technical information about $\mathrm{H}_{2} \mathrm{~S}$ and other gas hazards; and

- Copies of waiver forms.

\section{Distribution}

An electronic copy of this manual will be kept on the ODP Web site policy page. An annually updated hard copy of this manual will be kept in the offices of both the ODP Operations Manager and the ship's Offshore Installation Manager.

Both electronic and hard copies will be available to all personnel aboard the JOIDES Resolution.

\section{H$_{2}$ S HAZARD CONDITIONS}

There are five $\mathrm{H}_{2} \mathrm{~S}$ hazard conditions, excluding "normal operations" (Table T1). This manual provides a minimum set of guidelines for each hazard condition covering the following topics:

- $\mathrm{H}_{2} \mathrm{~S}$ monitoring,

- Precautions and special procedures,

- $\mathrm{H}_{2} \mathrm{~S}$ response, and

- Special concerns.

The $\mathrm{H}_{2} \mathrm{~S}$ hazard condition is set by the offshore installation manager based on the concentration of $\mathrm{H}_{2} \mathrm{~S}(\mathrm{ppm})$ in air, the type of $\mathrm{H}_{2} \mathrm{~S}$ source, the location of the detector (open air or confined space), and the relative distance of the detector from the $\mathrm{H}_{2} \mathrm{~S}$ source.

Table T1. Hydrogen sulfide operating conditions.

\begin{tabular}{lccll}
\hline & \multicolumn{2}{c}{$\mathrm{H}_{2} \mathrm{~S}(\mathrm{ppm})$ measured from } & & \\
\cline { 2 - 3 } $\mathrm{H}_{2} \mathrm{~S}$ condition & Open air & Core/Drill string & Danger to life & Action \\
\cline { 2 - 3 } Normal operations & $\mathrm{No} \mathrm{H}_{2} \mathrm{~S}$ potential & & None & None \\
Watch & Potential $\mathrm{H}_{2} \mathrm{~S}$ & & None & Monitor \\
Alert & $1-19$ & $\mathrm{NA}$ & None & Monitor, use BAs as needed \\
$\begin{array}{l}\text { Danger } \\
\text { Emergency }\end{array}$ & $20-49$ & $>20$ & Moderate & Stop coring operations \\
& $>50$ & NA & Extreme & Evacuate to safe areas \\
\hline
\end{tabular}

Notes: $\mathrm{BA}=$ fixed or portable self-contained breathing system. $\mathrm{NA}=$ not applicable.

\section{Common $\mathrm{H}_{2} \mathrm{~S}$ Sources}

The most common $\mathrm{H}_{2} \mathrm{~S}$ sources (see "Appendix B") on the JOIDES Resolution are

- Gases diffusing from recovered core and samples taken from the core; 
W.G. MILLS ET AL.

- Gases that have accumulated in the core barrel and escape when the core catcher and/or the core liner is removed;

- Gases that are "swabbed" up the drill string when a core, downhole tool, or logging tool is recovered and escape when the drill string is opened at the rig floor;

- Gases that escape from downhole or logging tools when opened in the laboratory after use;

- Gases displaced when the inner core barrel is washed out;

- Decomposition of recovered $\mathrm{H}_{2} \mathrm{~S}$ clathrates; and

- Well blowout that releases gases up through the drill string or into the surrounding waters.

In all these cases (except for clathrates and blowout situations), the source of $\mathrm{H}_{2} \mathrm{~S}$ is small in volume or must pass through a small opening first (i.e., the open end of the drill string) before reaching a work area.

\section{$\mathrm{H}_{2} \mathrm{~S}$ Detectors}

\section{Fixed-Area Detection Stations}

Fixed-area detection stations are mounted around the ship (see "Appendix $A^{\prime \prime}$ ) where $\mathrm{H}_{2} \mathrm{~S}$ sources are present or in areas where $\mathrm{H}_{2} \mathrm{~S}$ may accumulate. One or two sensors can be attached to each detection station. The stations are mounted in open areas and continuously monitor for $\mathrm{H}_{2} \mathrm{~S}$ in the work area atmosphere. The detection stations are connected via radio to an alarm control panel mounted on the ship's bridge. In addition, each station may have either an audio or a visual alarm, or both.

All fixed $\mathrm{H}_{2} \mathrm{~S}$ sensors are set to detect a minimum of $10 \mathrm{ppm}$. Warning lights and horn units are installed on each detector station. If $\mathrm{H}_{2} \mathrm{~S}$ is present at concentrations at or above $10 \mathrm{ppm}$, a local audible and visual alarm will sound in the hazardous area where $\mathrm{H}_{2} \mathrm{~S}$ is detected. At the same time, an audible and visual alarm will be triggered on the central alarm panel on the bridge.

For detailed operating instructions and specifications, see the manufacturer's operator manual.

\section{Portable Detectors}

The staff on the rig floor and core-receiving platform use handheld portable detectors to spot check for the presence of $\mathrm{H}_{2} \mathrm{~S}$. In addition, this style of detector can be used to monitor the work atmosphere.

\section{Personal Detectors}

Staff wear personal detectors while working directly with potential $\mathrm{H}_{2} \mathrm{~S}$ sources.

\section{$\mathrm{H}_{2} \mathrm{~S}$ Hazard Determination}

To determine the level of the $\mathrm{H}_{2} \mathrm{~S}$ hazard (see "Appendix $\mathrm{C}^{\text {"), it is }}$ important to remember the following facts:

- $\mathrm{H}_{2} \mathrm{~S}$ concentrations will diminish with distance from the source. 
W.G. MILLS ET AL.

- Moving air will greatly reduce the concentration of $\mathrm{H}_{2} \mathrm{~S}$ with distance from the source.

- Moving air can direct $\mathrm{H}_{2} \mathrm{~S}$ away from the sensor.

- $\mathrm{H}_{2} \mathrm{~S}$ is denser than air and will accumulate in unventilated rooms or in low areas on the ship (e.g., in the elevator well).

The following examples demonstrate why it is important to understand where and how $\mathrm{H}_{2} \mathrm{~S}$ was detected before assigning a hazard classification.

- $\mathrm{H}_{2} \mathrm{~S}$ has been swabbed up the drill pipe and released onto the drill floor when the pipe was opened to retrieve a core barrel. A fixed detector, mounted $20 \mathrm{ft}$ away and downwind from the open drill pipe, measures an $\mathrm{H}_{2} \mathrm{~S}$ level of 4 ppm (no alarm).

- On the core-receiving platform, a marine specialist measures 100 ppm of $\mathrm{H}_{2} \mathrm{~S}$ using a portable detector with the sampling tube inside the cut end of the core liner.

- The alarm of the $\mathrm{H}_{2} \mathrm{~S}$ station monitoring the refrigerated core storage has gone off.

In the first example, the $\mathrm{H}_{2} \mathrm{~S}$ level measured at the detector has been reduced by distance. It is possible that the concentration of $\mathrm{H}_{2} \mathrm{~S}$ near the open drill string is at a lethal level. In an open-air location, a fixed detector cannot be used as the primary means of $\mathrm{H}_{2} \mathrm{~S}$ detection. However, the detection of any $\mathrm{H}_{2} \mathrm{~S}$ by a fixed detector in an open-air location could indicate a very serious condition near the source. When a fixed detector is activated in an open-air setting, personnel not wearing a portable breathing apparatus (BA) must leave the work area immediately until the source has been discovered (using a portable detector) and the concentration of $\mathrm{H}_{2} \mathrm{~S}$ has dropped to a safe level.

In the second example, the $\mathrm{H}_{2} \mathrm{~S}$ measurement was taken directly at the source in a confined space. Because the staff working on the core-receiving platform are in an open-air environment, a measurement should be taken 12 in away from the core to determine the actual hazard level. If this measurement shows an $\mathrm{H}_{2} \mathrm{~S}$ level $>20 \mathrm{ppm}$, then BAs are only needed for individuals working directly over the core; other individuals working on the core-receiving platform do not need to wear a BA.

The third example is a serious situation because the detector is monitoring a confined space. Only individuals wearing BAs should enter this area to begin ventilation. Note, however, that $\mathrm{H}_{2} \mathrm{~S}$ readings taken in a confined space should not necessarily be used to determine $\mathrm{H}_{2} \mathrm{~S}$ hazard conditions for the entire ship.

\section{$\mathrm{H}_{2} \mathrm{~S}$ Hazard Responsibilities}

\section{Offshore Installation Manager}

- Understands the $\mathrm{H}_{2} \mathrm{~S}$ guidelines and policies set forth in this document and ensures that all personnel aboard the JOIDES Resolution observe the same;

- Informs the operations manager, ship's master, and shipboard supervisors of the current $\mathrm{H}_{2} \mathrm{~S}$ hazard condition; 
W.G. MILLS ET AL.

- May modify the policies in this document to fit the safety requirements of the situation; and

- Is qualified to conduct the shipboard $\mathrm{H}_{2} \mathrm{~S}$ safety training.

\section{Night Tool Pusher}

- Assists in carrying out the offshore installation manager's responsibilities listed above and

- Is qualified to conduct the shipboard $\mathrm{H}_{2} \mathrm{~S}$ safety training.

\section{ODP Operations Manager}

- Assists the offshore installation manager in enforcing the policies set forth in this document;

- Keeps ODP shipboard staff informed of the $\mathrm{H}_{2} \mathrm{~S}$ hazard situation;

- Keeps ODP onshore management informed of $\mathrm{H}_{2} \mathrm{~S}$ hazard situation; and

- Is qualified to conduct the shipboard $\mathrm{H}_{2} \mathrm{~S}$ safety training.

\section{Ship's Master and Officers}

When an $\mathrm{H}_{2} \mathrm{~S}$ emergency ( $>50 \mathrm{ppm}$ ) condition is encountered, the ship's master or ship's officer on duty is solely responsible for determining what action is required and, as necessary, sounding the general alarm to notify personnel to report to the designated safe-briefing area.

The ship's master or officer

- Designates the safe-briefing areas;

- Keeps all personnel advised of the current safe-briefing area;

- Notifies vessels and aircraft in the area of an $\mathrm{H}_{2} \mathrm{~S}$ emergency;

- Maintains both fixed and portable breathing systems in a safe and working order; and

- Maintains a 24-hr watch on the bridge to monitor the $\mathrm{H}_{2} \mathrm{~S}$ central alarm panel.

\section{Laboratory Officer}

- Is qualified to conduct the shipboard $\mathrm{H}_{2} \mathrm{~S}$ safety training;

- Provides $\mathrm{H}_{2} \mathrm{~S}$ training to the science party;

- Oversees technical staff in setting up, calibrating, and testing the $\mathrm{H}_{2} \mathrm{~S}$ detector systems;

- Posts $\mathrm{H}_{2} \mathrm{~S}$ warning signs;

- Assigns the $\mathrm{H}_{2} \mathrm{~S}$ safety technician's duties;

- Ensures that the scientific party has personal protection equipment (PPE) and knows how to use it;

- Documents all training and maintains training records; and

- Assists the offshore installation manager in enforcing the policies set forth in this document. 
W.G. MILLS ET AL.

Assistant Laboratory Officer

- Is qualified to conduct the shipboard $\mathrm{H}_{2} \mathrm{~S}$ safety training and

- Assists the laboratory officer in carrying out his responsibilities as listed above.

\section{Ship's Department Supervisor}

- Keeps staff (including the consultant and subcontractors) informed of the current $\mathrm{H}_{2} \mathrm{~S}$ hazard and

- Provides appropriate PPE and ensure that staff know how to use it.

\section{Core Technician}

- Monitors $\mathrm{H}_{2} \mathrm{~S}$ levels on the rig floor;

- Knows and executes the $\mathrm{H}_{2} \mathrm{~S}$ monitoring policies set forth in this document; and

- Keeps the offshore installation manager, operations manager, and $\mathrm{H}_{2} \mathrm{~S}$ safety technician advised of the $\mathrm{H}_{2} \mathrm{~S}$ situation in their work area.

\section{$\mathrm{H}_{2}$ S Safety Technician}

- Monitors $\mathrm{H}_{2} \mathrm{~S}$ levels on the core-receiving platform and in the core laboratory;

- Knows and executes the $\mathrm{H}_{2} \mathrm{~S}$ monitoring policies set forth in this document; and

- Keeps the offshore installation manager, operations manager, laboratory officer, and assistant laboratory officer advised of the $\mathrm{H}_{2} \mathrm{~S}$ situation in their work area.

\section{Ship's Physician}

- Confirms that personnel working in the hazardous areas do not have punctured eardrums;

- Ensures that the ship is stocked with any special medical supplies that may be needed for treating personnel exposed to $\mathrm{H}_{2} \mathrm{~S}$; and

- Assists with training in resuscitation and $\mathrm{H}_{2} \mathrm{~S}$ first aid.

\section{All Personnel}

All personnel working in the designated hazardous areas (rig floor, core-receiving platform, core laboratory, and reefer) must

- Be familiar with the procedures outlined in this document;

- Complete an $\mathrm{H}_{2} \mathrm{~S}$ safety training course;

- Be responsible for their PPE and that it is properly stored and easily accessible;

- Be familiar with the location of all safety equipment in their work area and be able to use it upon notice;

- Stay informed of the current $\mathrm{H}_{2} \mathrm{~S}$ hazard condition; and 
W.G. MILLS ET AL.

- Follow instructions set forth in this document or as provided by their supervisor.

\section{PREPARATION FOR $\mathrm{H}_{2} \mathrm{~S}$ OPERATIONS}

\section{General}

$\mathrm{H}_{2} \mathrm{~S}$ detection equipment, training materials, and warning signs must be kept on board the JOIDES Resolution and in an operational state for every leg, regardless if $\mathrm{H}_{2} \mathrm{~S}$ is expected or not. Responsible positions are defined in the following sections.

\section{Precruise}

All ship personnel are tested for perforated eardrums as part of their medical exam. Individuals with perforated eardrums will be permitted to work with or in proximity to $\mathrm{H}_{2} \mathrm{~S}$ cores provided they sign an indemnity wavier (see "Appendix $F^{\prime}$ ") and do not work in any areas where a BA is required because of $\mathrm{H}_{2} \mathrm{~S}$.

The laboratory officer ensures that all $\mathrm{H}_{2} \mathrm{~S}$ safety equipment that has been returned to the vendor for repair is fixed and sent back to the ship and that an adequate supply of calibration gases is on board before the ship leaves port.

\section{Before Arriving on Site Where $\mathrm{H}_{2} \mathrm{~S}$ is Expected}

\section{Training}

$\mathrm{H}_{2} \mathrm{~S}$ safety training courses are held for all shipboard personnel, and records are kept for all who attend. The laboratory officer will conduct this training for the science party as part of their specific hazard training. The original record of training is sent to ODP and filed with the human resources office. A copy is kept on board, filed in the laboratory officer's office. The offshore installation manager will conduct this training for the ship staff.

$\mathrm{H}_{2} \mathrm{~S}$ safety training covers

- General safety concepts, procedures, and policies of this document;

- Location and use of air breathing equipment;

- Hazards of $\mathrm{H}_{2} \mathrm{~S}$;

- First aid for $\mathrm{H}_{2} \mathrm{~S}$ victims;

- How to operate personal and portable $\mathrm{H}_{2} \mathrm{~S}$ detectors; and

- Becoming "wind-conscious" (aware of the direction of the prevailing winds at all times).

\section{Ship's Captain}

- Conducts at least one $\mathrm{H}_{2} \mathrm{~S}$ evacuation drill and

- Opens the upper air intake and closes the lower air intake on the ship's air-conditioning plenum. 
W.G. MILLS ET AL.

Offshore Installation Manager

The offshore installation manager conducts blowout drills until supervisors are satisfied that rig floor personnel can install the drill pipe safety valve while using breathing equipment.

\section{Laboratory Officer}

- Posts $\mathrm{H}_{2} \mathrm{~S}$ warning signage;

- Establishes the core-receiving platform as a NO SMOKING area;

- Mounts the fixed $\mathrm{H}_{2} \mathrm{~S}$ detectors and alarms at locations noted in "Appendix A;"

- Calibrates and tests fixed, portable, and personal $\mathrm{H}_{2} \mathrm{~S}$ detectors;

- Distributes portable and personal $\mathrm{H}_{2} \mathrm{~S}$ to staff as needed and makes sure that the staff know how to operate detectors;

- Designates two $\mathrm{H}_{2} \mathrm{~S}$ safety technicians for 24-hr coverage; and

- Places emergency air escape packs (three each, 5 min of air) inside the elevator.

\section{Ship's Officers}

- Install wind direction indicators per "Appendix B" and

- Ensure that both portable and fixed BA systems are in operating order.

\section{NORMAL OPERATIONS}

During normal drilling operations, $\mathrm{H}_{2} \mathrm{~S}$ is typically first detected by odor $(<1 \mathrm{ppm})$. When $\mathrm{H}_{2} \mathrm{~S}$ odor is detected, the offshore installation manager should be notified immediately. After consultation with the operations manager and scientists, the offshore installation manager determines whether invoke one of the $\mathrm{H}_{2} \mathrm{~S}$ hazard conditions.

During an $\mathrm{H}_{2} \mathrm{~S}$ hazard condition of ALERT or higher, all drilling operations are suspended until the presite $\mathrm{H}_{2} \mathrm{~S}$ preparations are completed, including $\mathrm{H}_{2} \mathrm{~S}$ safety training, which can be given to each shift before they start work.

In addition, the offshore installation manager can permit drilling operations to resume while fixed-station detectors are being installed, provided portable detectors are available for monitoring and $\mathrm{H}_{2} \mathrm{~S}$ levels do not exceed $20 \mathrm{ppm}$ when measured at the drill string or core.

At a minimum, a fixed detector must be installed on the rig floor and on the core-receiving platform.

\section{Unexpected $\mathrm{H}_{2} \mathrm{~S}$ Release}

In case of an unplanned or unexpected release of $\mathrm{H}_{2} \mathrm{~S}$ gas, all personnel should

- Hold their breath if air breathing equipment is not available;

- Rapidly evacuate the area containing the $\mathrm{H}_{2} \mathrm{~S}$ and move upwind if possible;

- Move up a deck to get upwind of the source; 
W.G. MILLS ET AL.

- If available, put on a BA;

- Evacuate anyone who may be affected by the gas to a safe area; administer resuscitation or oxygen as needed or call the ship's doctor;

- Put on air breathing equipment before helping anyone overcome by $\mathrm{H}_{2} \mathrm{~S}$;

- Quickly evacuate to the assigned or announced safe-briefing area to receive instructions from supervisory personnel; and

- Not panic.

\section{$\mathrm{H}_{2} S$ OPERATIONS}

The location, source, and concentration of $\mathrm{H}_{2} \mathrm{~S}$ when detected are important in determining the potential $\mathrm{H}_{2} \mathrm{~S}$ hazard condition and resulting actions. The following guidelines address the various locations and activities where $\mathrm{H}_{2} \mathrm{~S}$ might be encountered.

\section{$\mathrm{H}_{2} \mathrm{~S}$ Monitoring Responsibilities}

\section{Bridge}

The ship's officers provide 24-hr monitoring of the central $\mathrm{H}_{2} \mathrm{~S}$ alarm panel while operating on a $\mathrm{H}_{2} \mathrm{~S}$ site. When an alarm goes off on this panel, it is the responsibility of the ship's officer to take the appropriate action.

Table $\mathbf{T} 2$ is provided for guidance only and may be modified by the offshore installation manager and the ship's master as the situation and experience with the local $\mathrm{H}_{2} \mathrm{~S}$ environment dictates.

Table T2. Hydrogen sulfide alarm locations.

\begin{tabular}{ll}
\multicolumn{1}{c}{ Alarm area } & \multicolumn{1}{c}{ Action } \\
\hline Core laboratory & Notify $\mathrm{H}_{2} \mathrm{~S}$ safety technician \\
Core receiving platform* & ${\text { Notify } \mathrm{H}_{2} \mathrm{~S} \text { safety technician }}_{\text {Core entry }}$ \\
Notify $\mathrm{H}_{2} \mathrm{~S}$ safety technician \\
Core catcher bench* & Notify $\mathrm{H}_{2} \mathrm{~S}$ safety technician \\
Lower 'tween deck landing & Notify laboratory officer and investigate \\
Hold 'tween deck landing & Notify laboratory officer and investigate \\
Fresh air intake plenum* & Shut down intake fans and investigate \\
Rig floor* & Notify core technician \\
Multiple alarms on "*" detectors above & Sound alarm using coded bell signals and announce $\mathrm{H}_{2} \mathrm{~S}$ \\
Possible blowout! & EMERGENCY via public address system \\
&
\end{tabular}

\section{Rig Floor}

The two core technicians are responsible for monitoring $\mathrm{H}_{2} \mathrm{~S}$ levels on the rig floor during their shift to provide 24-hr coverage. The core technician works under the authority of the offshore installation manager and the night tool pusher. Note that in the following instructions, references to the offshore installation manager include the night tool pusher or other offshore installation manager designee. 
W.G. MILLS ET AL.

Core Receiving Platform, Core Laboratory, and Core Storage Areas

The $\mathrm{H}_{2} \mathrm{~S}$ safety technicians are two marine specialists assigned the responsibility for monitoring $\mathrm{H}_{2} \mathrm{~S}$ levels on the core-receiving platform and in the core laboratory. There is an $\mathrm{H}_{2} \mathrm{~S}$ safety technician assigned to each shift for 24-hr coverage. The $\mathrm{H}_{2} \mathrm{~S}$ safety technicians work under the authority of the laboratory officer and assistant laboratory officer.

\section{Downhole and Logging Tools}

The technicians operating these tools are responsible for monitoring any $\mathrm{H}_{2} \mathrm{~S}$ that maybe trapped inside the tool.

\section{General Safety Practices}

- Use fans to ventilate work areas. Fans can keep the $\mathrm{H}_{2} \mathrm{~S}$ concentration low enough so that BAs are not required;

- If stationkeeping permits, head the ship so that the wind hits the ship just off the port bow, blowing across the core-receiving platform and through the rig floor;

- Always use the buddy system when working in potentially hazardous areas;

- Always check PPE at the beginning of the work shift. Never assume that someone has left it in working order; and

- Do not let materials pile up around fixed $\mathrm{H}_{2} \mathrm{~S}$ sensors.

\section{Opening the Drill String on the Drill Floor}

The following guidelines apply when retrieving a core barrel or other tools deployed through the drill string.

\section{$\mathrm{H}_{2} \mathrm{~S}$ Monitoring}

The core technician is responsible for monitoring $\mathrm{H}_{2} \mathrm{~S}$ levels on the drill floor with a portable detector. The drill pipe opening (while opening), upper drill string connection, top of inner core barrel, and bottom of core catcher sub are areas that should be monitored.

\section{Precautions and Special Procedures}

Table T3 gives guidance on who must wear a BA before opening the drill string and measuring the $\mathrm{H}_{2} \mathrm{~S}$ levels.

Table T3. Breathing apparatus required before opening drill string.

\begin{tabular}{lccc}
\hline $\begin{array}{c}\mathrm{H}_{2} \mathrm{~S} \text { hazard } \\
\text { condition }\end{array}$ & $\begin{array}{c}\text { Core } \\
\text { technician }\end{array}$ & $\begin{array}{c}\text { Rig floor } \\
\text { crew }\end{array}$ & $\begin{array}{c}\text { Driller } \\
\text { (driller's shack) }\end{array}$ \\
\hline Watch & No & No & No \\
Alert & No & No & No \\
Danger & Yes & Yes & No \\
Emergency & Yes & Yes & Yes \\
\hline
\end{tabular}


W.G. MILLS ET AL.

\section{$\mathrm{H}_{2} \mathrm{~S}$ Response}

When $\mathrm{H}_{2} \mathrm{~S}$ is detected at the drill pipe, the following procedures must be implemented, depending on the concentration detected and how it was measured.

\section{1-19 ppm, Measured with a Portable Detector at the Drill Pipe}

After a positive reading, the core technician notifies the offshore installation manager, who may change the $\mathrm{H}_{2} \mathrm{~S}$ hazard condition to ALERT.

\section{0-49 ppm, Measured with a Portable Detector at the Drill Pipe}

- The rig floor crew working around the drill pipe put on BAs.

- The drill pipe is reconnected and circulation begins.

- The core technician notifies the offshore installation manager and operations manager.

- After the drill string has been completely flushed, the pipe is reopened and $\mathrm{H}_{2} \mathrm{~S}$ levels are checked. If they are still $>20$ ppm, steps 2 through 4 are repeated unless otherwise instructed by the offshore installation manager.

- The offshore installation manager may change the $\mathrm{H}_{2} \mathrm{~S}$ hazard condition to DANGER.

$>50$ ppm, Measured with a Portable Detector at the Drill Pipe or $\geq 10$ ppm at Rig Floor's Fixed Station

- The rig floor crew, including the driller, put on BAs.

- Personnel on the core-receiving platform put on BAs or evacuate the area.

- The drill pipe is reconnected and circulation begins.

- The core technician notifies the offshore installation manager and operations manager of the situation.

- Personnel wait for instructions from the offshore installation manager.

- The offshore installation manager may change the $\mathrm{H}_{2} \mathrm{~S}$ hazard condition to EMERGENCY and notify the ship's master to sound alarms and evacuate ship personnel to safe areas.

\section{Special Concerns}

\section{$\mathrm{H}_{2} \mathrm{~S}$ Blowout}

Although unlikely, a set of circumstances could occur that would cause an $\mathrm{H}_{2} \mathrm{~S}$ blowout to discharge gas up the drill string. The first sign that this situation is occurring would be backflow when the drill string is opened. There are many situations other than a blowout that can cause backflow, but while drilling in an environment where $\mathrm{H}_{2} \mathrm{~S}$ is present the following steps should be taken if backflow is detected unless otherwise instructed by the offshore installation manager:

- The drill string is reconnected as quickly as possible.

- The core technician checks atmosphere for $\mathrm{H}_{2} \mathrm{~S}$.

- The core technician notifies the offshore installation manager and operations manager of situation. 
W.G. MILLS ET AL.

- Technicians await instructions from the offshore installation manager.

\section{Removing Core from Core Barrel on the Drill Floor $\mathrm{H}_{2} \mathrm{~S}$ Monitoring}

The core technician is responsible for monitoring $\mathrm{H}_{2} \mathrm{~S}$ levels on the drill floor with a portable detector. The bottom of the core catcher sub and bottom of the core barrel (after removing the core catcher) should be monitored.

\section{Precautions and Special Procedures}

Table $\mathbf{T} 4$ provides guidance to determine who must wear a BA before the removing the core catcher and measuring the $\mathrm{H}_{2} \mathrm{~S}$ levels.

Table T4. Breathing apparatus required before removing core catcher.

\begin{tabular}{lccc}
\hline $\mathrm{H}_{2}$ S hazard condition & $\begin{array}{c}\text { Core } \\
\text { technician }\end{array}$ & $\begin{array}{c}\text { Rig floor } \\
\text { crew }\end{array}$ & $\begin{array}{c}\text { Core } \\
\text { handlers }\end{array}$ \\
\hline Watch (potential) & No & No & No \\
Alert (1-19 ppm) & No & No & No \\
Danger (20-49 ppm) & Yes & Yes & Yes \\
Emergency $(>50$ ppm) & Yes & Yes & Yes \\
\hline
\end{tabular}

\section{$\mathrm{H}_{2} \mathrm{~S}$ Response}

If $\mathrm{H}_{2} \mathrm{~S}$ is detected from the core barrel, the following procedures are implemented.

1-19 ppm, Measured with a Portable Detector at the Core Barrel

- The core technician notifies the $\mathrm{H}_{2} \mathrm{~S}$ safety technician.

- The core technician notifies the offshore installation manager and operations manager. The offshore installation manager may change the $\mathrm{H}_{2} \mathrm{~S}$ hazard condition to ALERT.

>20 ppm, Measured with a Portable Detector at the Core Barrel

- The rig floor crew opening the core barrel and the core handlers put on BAs.

- The core technician notifies the $\mathrm{H}_{2} \mathrm{~S}$ safety technician.

- The core technician notifies the offshore installation manager and operations manager. The offshore installation manager may change the $\mathrm{H}_{2} \mathrm{~S}$ hazard condition to DANGER.

$\geq 10$ ppm, Measured at the Rig Floor's Fixed Station

- The rig floor crew, including the driller, put on BAs.

- Personnel on the core-receiving platform put on BAs or evacuate the area.

- The core technician locates the source of the $\mathrm{H}_{2} \mathrm{~S}$ and notifies the offshore installation manager and operations manager of the situation. 
- Technicians wait for instructions from the offshore installation manager.

- The offshore installation manager may change the $\mathrm{H}_{2} \mathrm{~S}$ hazard condition to EMERGENCY and then notifies the ship's master to sound alarms and evacuate ship's personnel to safe areas.

\section{Core Processing on the Core-Receiving Platform}

\section{$\mathrm{H}_{2} \mathrm{~S}$ Monitoring}

The $\mathrm{H}_{2} \mathrm{~S}$ safety technician is responsible for monitoring $\mathrm{H}_{2} \mathrm{~S}$ levels on the core-receiving platform with a portable detector. The core (vent holes and cut ends), 12 in above the core, the core catcher, and core storage racks (outside the laboratory) should be monitored.

\section{Precautions and Special Procedures}

\section{Moving Core from Rig Floor to Core Rack}

- Before the core handlers receive the core from the rig floor, the $\mathrm{H}_{2} \mathrm{~S}$ level is measured, as described in the section above. If $\mathrm{H}_{2} \mathrm{~S}$ levels are $>20 \mathrm{ppm}$ at the core barrel, core handlers wear BAs while transferring the core from the rig floor to the core rack.

- Core handlers should hold the core at waist level when moving it to the core rack. The core should not be placed on the shoulder or held anywhere near the face. If the core liner ruptures, the face will have more protection from sharp core liner fragments and direct exposure to $\mathrm{H}_{2} \mathrm{~S}$.

- When working with very gassy cores, face shields and Kevlar aprons, sleeve protectors, and gloves should be worn. The $\mathrm{H}_{2} \mathrm{~S}$ safety technician determines when this special protection is needed.

\section{Curating Core on the Core Rack}

- After the core is placed in the core rack, 1/8-in diameter holes are drilled through the liner to depressurize the core. The holes should not be drilled in a straight line, as this can cause a core liner to rupture. Rather, the holes should be staggered around the circumference and spaced apart as necessary.

- As gas vents, $\mathrm{H}_{2} \mathrm{~S}$ levels are monitored. Vent holes are checked to see if $\mathrm{H}_{2} \mathrm{~S}$ is present.

- $\mathrm{H}_{2} \mathrm{~S}$ levels at the surface of the core liner determine if core handlers and other personnel working on the core-receiving platform need to wear BAs (See " $\mathrm{H}_{2} \mathbf{S}$ Emergency Condition").

- The core is not cut into sections until after depressurization, to keep material from being extruded out of the liner.

- If any part of a core contains $\mathrm{H}_{2} \mathrm{~S}$, the core liner of each section and all whole-round samples are marked with " $\mathrm{H}_{2} \mathrm{~S}$ " $\mathrm{H}_{2} \mathrm{~S}$ warning stickers may be used, as well.

Moving Core Sections into the Core Entry Area of the Core Laboratory

- Sections of whole cores may be brought into core entry area provided that the core has depressurized and is no longer actively 
venting gas (i.e., causing core expansion gaps) and any remaining $\mathrm{H}_{2} \mathrm{~S}$ diffusing from the core is $<20 \mathrm{ppm}$ when measured 12in above the core.

- Sections of core that do not meet the above criteria remain outside until they do.

- Vent holes and end caps are sealed with tape if the $\mathrm{H}_{2} \mathrm{~S}$ level is $>10$ ppm measured 12-in above the core.

\section{$\mathrm{H}_{2} \mathrm{~S}$ Response}

When $\mathrm{H}_{2} \mathrm{~S}$ is detected above the core liner during venting, the following procedures are followed.

1-9 ppm, Measured with a Portable Detector at the Surface of the Core Liner

- BAs are not required.

- The $\mathrm{H}_{2} \mathrm{~S}$ safety technician continues monitoring until the core has depressurized (as defined above).

- The $\mathrm{H}_{2} \mathrm{~S}$ safety technician notifies the offshore installation manager and operations manager.

- The offshore installation manager may change the $\mathrm{H}_{2} \mathrm{~S}$ hazard condition to ALERT.

>10 ppm, Measured with a Portable Detector 12 in above the Core

- BAs are required for core handlers. All other individuals on the corereceiving platform MUST leave the area.

- The $\mathrm{H}_{2} \mathrm{~S}$ safety technician continues monitoring until core has depressurized (as defined above).

- The $\mathrm{H}_{2} \mathrm{~S}$ safety technician notifies the offshore installation manager and operations manager. The offshore installation manager may change the $\mathrm{H}_{2} \mathrm{~S}$ hazard condition to HAZARD or higher.

$\geq 10$ ppm, Measured at the Core-Receiving Platform's Fixed Station

- BAs are required for core handlers. All other individuals on the corereceiving platform MUST leave the area.

- The $\mathrm{H}_{2} \mathrm{~S}$ safety technician identifies the source of $\mathrm{H}_{2} \mathrm{~S}$ and notifies the offshore installation manager and operations manager of the situation.

- Wait for instructions from the offshore installation manager.

- The offshore installation manager may change the $\mathrm{H}_{2} \mathrm{~S}$ hazard condition to EMERGENCY and notify the ship's master to sound alarms and evacuate ship's personnel to safe areas.

\section{Special Concerns}

\section{$\mathrm{H}_{2} \mathrm{~S}$ Clathrates}

Clathrates (gas hydrates) are crystalline substances composed principally of three-dimensional cages of water in which various gases (e.g., $\mathrm{CH}_{4}$ and $\mathrm{H}_{2} \mathrm{~S}$ ) can enter and stabilize the structure. At room temperature and pressure, a clathrate will disassociate, releasing a volume of $\mathrm{H}_{2} \mathrm{~S}$ gas that can be greater than the original volume of the clathrate. 
If a clathrate is recovered from a site where $\mathrm{H}_{2} \mathrm{~S}$ is expected, the following steps should be taken:

- Core Handlers wear BAs.

- Personnel not handling core leave the core-receiving platform.

- The section of the core containing the clathrate is cut out.

- $\mathrm{H}_{2} \mathrm{~S}$ is quickly measured while the clathrate is being removed.

- The clathrate is processed according to the scientist's instructions. Usually this involves placing the clathrate in a pressure container or into liquid $\mathrm{N}_{2}$.

- If $\mathrm{H}_{2} \mathrm{~S}$ is detected, place an $\mathrm{H}_{2} \mathrm{~S}$ warning label on the container.

- The $\mathrm{H}_{2} \mathrm{~S}$ safety technician notifies the offshore installation manager the first time a clathrate is recovered at a particular site.

An $\mathrm{H}_{2} \mathrm{~S}$ clathrate may only be brought into the laboratory in a sealed pressure container. Liquid $\mathrm{N}_{2}$ dewars holding $\mathrm{H}_{2} \mathrm{~S}$ clathrates are stored outdoors, away from supply ventilations and sources of ignition, and are marked with warning signs.

\section{Core Processing in the Core Laboratory}

\section{$\mathrm{H}_{2}$ S Monitoring}

The marine specialists and the $\mathrm{H}_{2} \mathrm{~S}$ safety technicians are responsible for monitoring $\mathrm{H}_{2} \mathrm{~S}$ levels in the core laboratory with a portable detector. Core storage racks (inside the laboratory), air in the core splitting room, the cut surface of split cores after splitting, and the cut surface of split cores while laying out in the core laboratory are monitored.

\section{Precautions and Special Procedures}

While cores are waiting to be split or measured on the multisensor track (MST), they continue to warm up and may possibly resume degassing. Should this happen, the marine specialists remeasure the $\mathrm{H}_{2} \mathrm{~S}$ levels. If the $\mathrm{H}_{2} \mathrm{~S}$ level is $<10 \mathrm{ppm}$, the core may remain in the laboratory. If it is $>10 \mathrm{ppm}$, the core is removed from the laboratory until it can be sealed as mentioned in the previous section. Warning: cores that are no longer actively emitting $\mathrm{H}_{2} \mathrm{~S}$ may release additional $\mathrm{H}_{2} \mathrm{~S}$ during the core splitting process (especially if the super saw is used). The $\mathrm{H}_{2} \mathrm{~S}$ levels from split cores are often greater than the levels measured in the whole round.

Prior to splitting cores two BAs must be available and ready for use. There must be at least two marine specialists in the splitting room when a core is split. During the splitting process the $\mathrm{H}_{2} \mathrm{~S}$ levels are continuously monitored with a handheld detector. If the $\mathrm{H}_{2} \mathrm{~S}$ level in the splitting room is $>20 \mathrm{ppm}$, core splitting stops and the two the marine specialists cutting the core put on their BAs; all others leave the room.

Cores may be taken back outside the laboratory to finish degassing or left on the splitting table, covered, and vented using the flexible exhaust duct provided in the splitting room (Fig. F1). Core halves do not leave the splitting room until all signs of active degassing have stopped and the remaining $\mathrm{H}_{2} \mathrm{~S}$ concentration from the core is $<10 \mathrm{ppm}$. Note: some individuals may be very sensitive to low levels of $\mathrm{H}_{2} \mathrm{~S}$. The 10-

F1. Core on splitting table, p. 33.

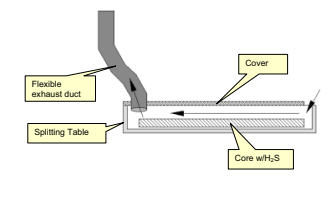


W.G. MILLS ET AL.

ppm level may have to be set lower for these individuals or a BA provided for them to use.

All D-tubes and core boxes holding cores that have emitted $\mathrm{H}_{2} \mathrm{~S}$ are tagged with $\mathrm{H}_{2} \mathrm{~S}$ warning labels. $\mathrm{H}_{2} \mathrm{~S}$ warning signs are placed on core refrigerators where these cores are stored.

To keep the air fresh in the core laboratory,

- Fully open the fresh air supply to the core laboratory and top deck air handlers;

- Open doors and windows, if weather permits; and

- Use fans to force additional fresh air into the laboratory.

\section{$\mathrm{H}_{2} \mathrm{~S}$ Response}

When $\mathrm{H}_{2} \mathrm{~S}$ is detected in the core Laboratory, the following procedure must be followed.

$\geq 10$ ppm at any Fixed Station in the Core Laboratory

- The immediate area is evacuated.

- The $\mathrm{H}_{2} \mathrm{~S}$ safety technician identifies the source of $\mathrm{H}_{2} \mathrm{~S}$ and notifies the laboratory officer of the situation.

- Technicians wait for instructions from the laboratory officer.

\section{Handling Downhole and Logging Tools at Various Locations}

\section{$\mathrm{H}_{2} \mathrm{~S}$ Monitoring}

Because each tool is unique, it is the responsibility of the technician operating the tool to carefully check for $\mathrm{H}_{2} \mathrm{~S}$ in sampling chambers or for $\mathrm{H}_{2} \mathrm{~S}$ trapped inside the tool's housing.

\section{Precautions and Special Procedures}

If the $\mathrm{H}_{2} \mathrm{~S}$ hazard condition is ALERT (1-19 ppm) or higher, then the tool's sampling chambers are vented outside or in a controlled manner such that there is no chance of $\mathrm{H}_{2} \mathrm{~S}$ escaping into the work area. The laboratory officer will approve such controls prior to tool's operation.

Should the technician suspect the tool's housing has been compromised and may possibly contain fluids or materials with $\mathrm{H}_{2} \mathrm{~S}$, the technician opens the housing in an open-air location.

If samples collected are transferred to another container, that container must have an $\mathrm{H}_{2} \mathrm{~S}$ warning tag (see "Pressure Core Samplers, Autoclaves, Transfer/Storage/Logging Containers, and Sampling Manifolds").

\section{$\mathrm{H}_{2} \mathrm{~S}$ Response}

If $\mathrm{H}_{2} \mathrm{~S}$ is released, the immediate area is evacuated until the air is tested. 
W.G. MILLS ET AL.

Pressure Core Samplers, Autoclaves, Transfer/Storage/ Logging Containers, and Sampling Manifolds

Downhole tools that return core/gas/liquid under pressure must comply with the following.

All pressure corers and pressurized transfer/storage/logging containers must have a written operator's manual that has been submitted to and approved by ODP and the ship operator's management prior to deploying the tool on the JOIDES Resolution. The manual must not only instruct the user on safe operation of the tool but also clearly state the types of hazards the tool presents to the operator. In regard to the potential release of $\mathrm{H}_{2} \mathrm{~S}$, the operator must be informed of all potential locations on the tool where pressure containment could fail (seals, valves, rupture disks, etc.).

When a pressure sampler is retrieved on the rig floor, all potential locations for containment failure must be surveyed with a handheld detector.

If the contents of the pressure sampler are transferred to secondary sample chamber or into a manifold/collection system, a handheld detector must be used to monitor the transfer operation.

When operating in a WATCH $\left(\mathrm{H}_{2} \mathrm{~S}\right.$ potential) or higher $\mathrm{H}_{2} \mathrm{~S}$ hazard condition, then it must be assumed that the pressure sampler or transfer/storage/logging container contains $\mathrm{H}_{2} \mathrm{~S}$ until the trapped gases can be sampled and determined otherwise. The following applies to both pressure samplers and transfer containers:

- Pressure samplers and transfer/storage/logging containers are tagged with an $\mathrm{H}_{2} \mathrm{~S}$ hazard label.

- Pressure samplers and transfer/storage/logging containers are surveyed with a handheld detector each time they are relocated to a new storage area.

- Personnel handling pressure samplers and transfer/storage/logging containers indoors wear a personal detector.

- $\mathrm{H}_{2} \mathrm{~S}$ warning signs are posted in areas where the pressure samplers and transfer/storage/logging containers are stored.

- Pressure samplers and transfer/storage/logging containers are vented outdoors in a location where personnel downwind are not affected.

\section{SPECIAL CORING PROCEDURES FOR $\mathrm{H}_{2} \mathrm{~S}$ SITES}

\section{Guidelines}

The following guidelines should be used unless otherwise instructed by the offshore installation manager.

- Maintain circulation while a core barrel is dropped or wirelined into and out of the hole.

- Control wireline speeds to prevent/minimize swabbing of $\mathrm{H}_{2} \mathrm{~S}$ bearing fluids into the drill string from the well bore.

- Engage the core barrel with the overshot.

- Stop the pumps, if necessary, while unseating the core barrel from the outer core barrel assembly (OCB). 
W.G. MILLS ET AL.

- Pull the core barrel up slowly above the top of the bottom-hole assembly (BHA).

- Stop the wireline winch once the core barrel is pulled above the top of the BHA.

- Pump three volumes of fluid (equal to the volume required to fill the inside of the BHA) to clear any $\mathrm{H}_{2} \mathrm{~S}$-bearing fluid that may have been swabbed into the BHA when the core barrel was unseated.

See "Opening the Drill String on the Drill Floor" for additional operational safety information.

\section{Rig Floor}

\section{Drill Pipe Safety Valve}

A drill pipe safety valve is kept on the rig floor. The valve can be used to prevent excessive backflow of fluid through the drill string. Such backflow could be the result of a hydrocarbon or hydrothermal fluid "kick." Either could possibly carry $\mathrm{H}_{2} \mathrm{~S}$ to the surface.

Install the valve in the drill string if excessive backflow occurs and the top drive is not readily available (i.e., racked back) for immediate makeup to the drill string.

\section{Baker Float Valve}

Once the safety valve is in place and closed, a second sub containing a float valve assembly can be made up on top of the safety valve.

The Baker model G (5F-6R) float valve acts as a check valve allowing drilling fluid to be pumped down the drill string while preventing hot or $\mathrm{H}_{2} \mathrm{~S}$-contaminated well bore fluids from backflowing up the drill string.

The drill pipe safety valve and Baker float valve assemblies are to be used under special circumstances only (i.e., when the top drive is not installed or is otherwise inoperable for circulation). Note that if the Baker float valve is installed, no downhole tools can be deployed.

\section{Downhole}

\section{BHA Installed Float Valves}

The rotary core barrel (RCB) BHA is equipped with a float (flapper) valve that is compatible with the RCB wireline coring system. The advanced piston corer/extended core barrel/pressure core sampler (APC/ $\mathrm{XCB} / \mathrm{PCS}$ ) BHA can be equipped with a lockable float (flapper) valve (LFV).

Each of these float valves serves to prevent excessive drill cuttings from "U-tubing" or being swabbed up into the BHA during core barrel retrieval. When functional, these flappers seal the throat of the core bit and prevent backflow into the drill string via that path. It should be noted, however, that neither of the BHA float valves seal the bit jets, and therefore they do not completely seal off the lower end of the drill string from the well bore.

The 63/4-in drill collar/BHA used with the advanced diamond coring barrel (ADCB) coring system is not compatible with either of the float valves used with the $\mathrm{RCB}$ or the $\mathrm{APC} / \mathrm{XCB} / \mathrm{PCS}$ coring systems. It has 
W.G. MILLS ET AL.

been suggested, therefore, that use of the ADCB coring system be avoided in formations where $\mathrm{H}_{2} \mathrm{~S}$ might be present.

\section{SPECIAL LOGGING PROCEDURES FOR $\mathrm{H}_{2} \mathrm{~S}$ SITES}

The following guidelines should be used unless otherwise instructed by the offshore installation manager:

- Maintain circulation while wireline tools are run into and out of the hole.

- Control wireline speeds to prevent swabbing $\mathrm{H}_{2} \mathrm{~S}$ fluids into the drill string from the well bore.

- Stop the tool above the top of the BHA once sampling or measurements are completed and the wireline tool(s) is/are retrieved inside the BHA.

- Pump three volumes of fluid (equal to the volume of fluid required to fill the inside of the BHA) to clear any $\mathrm{H}_{2} \mathrm{~S}$-rich fluid that may have been swabbed into the BHA as the tool was pulled inside it.

See "Handling Downhole and Logging Tools at Various Locations" for additional safety information. Do not use excessive flow rates that may be sufficient to fail cablehead weak points and pump the wireline tools off the wireline (this has happened in the past). Components that are not designed for operation in $\mathrm{H}_{2} \mathrm{~S}$ and $\mathrm{CO}_{2}$ environments are susceptible to sulfide and stress corrosion cracking. The cracking may occur downhole or at the surface over relatively short periods of time.

\section{$\mathrm{H}_{2}$ S EMERGENCY CONDITION}

\section{Instructions}

When an $\mathrm{H}_{2} \mathrm{~S}$ EMERGENCY ( $>50 \mathrm{ppm}$ ) condition has been called by the offshore installation manager, implement the following procedure:

1. All rig floor personnel put on BAs and remain on the rig floor unless otherwise instructed by the offshore installation manager.

2. All drilling/coring operations stop and the driller makes the string back up (if open), picks up off bottom, and maintains circulation.

3. The offshore installation manager notifies the ship's officers and operations manager of the situation.

4. The ship's officers sound the alarm using coded bell signals and verbally announce to all personnel via the public address system that an $\mathrm{H}_{2} \mathrm{~S}$ EMERGENCY exists and to report to a safe-briefing area.

5. The ship's officers shut down the ventilation systems.

6. The ship's officers notify any nearby vessels to go upwind and maintain a radio and visual watch.

7. At the safe briefing the ship's officers (or designees) take roll and account for all ship personnel. 
8. The ship's emergency response team, using BAs, make maximum effort to determine the source of the $\mathrm{H}_{2} \mathrm{~S}$ and suppress the $\mathrm{H}_{2} \mathrm{~S}$ as quickly as possible.

9. All personnel not assigned to emergency duties or working on the rig floor report to the upwind safe-briefing area for further instructions.

10. Drilling/coring operations remain suspended until the source of $\mathrm{H}_{2} \mathrm{~S}$ is located and the atmospheric level falls to a level $<10 \mathrm{ppm}$.

11. The buddy system is utilized for all personnel remaining in the potential danger area.

12. The hole may be terminated, depending on the source of the $\mathrm{H}_{2} \mathrm{~S}$, by the offshore installation manager.

13. The operations manager notifies the appropriate personnel on shore as soon as possible of the situation and the actions taken.

14. The driller is notified if the exhaust fans in the laboratory stack are turned on to exhaust $\mathrm{H}_{2} \mathrm{~S}$ because the exhaust fans discharge air above the rig floor.

\section{Safe-Briefing Area}

The primary safe-briefing areas are the port and starboard lifeboat stations located forward on the fo'c'sle deck. The port and starboard lifeboat stations are the safe-briefing areas because when the drillship is in dynamic-positioning (DP) mode, the bow of the ship is nearly always oriented into the prevailing wind.

The routes to the safe-briefing area are determined by the master and reviewed in safety meetings held with personnel working in each area of the ship. The best route from each location on the ship is dictated by rig floor activity, weather, and sea conditions.

All personnel not assigned emergency duties who are aft (i.e., back by the helideck) of the rig floor proceed forward to the safe-briefing stations along the mezzanine or main deck on the windward side of the ship. Personnel must avoid entering areas designated as potential $\mathrm{H}_{2} \mathrm{~S}$ danger areas as they proceed forward to the safe-briefing areas.

If, for some reason, the stern of the ship is oriented into the wind, the master announces to all ship personnel that the safe-briefing area is the helideck. The location of the designated safe-briefing area is posted by the master or mates next to the ship's station bills (where lifeboat assignments are posted) on each deck.

\section{PERSONNEL RESCUE}

It is possible that gases other than $\mathrm{H}_{2} \mathrm{~S}$ may be encountered, but they pose a much lower hazard (see "Appendix D" and "Appendix E"). In general, the measures taken to protect against $\mathrm{H}_{2} \mathrm{~S}$ exposure will also be effective against other gases.

When $\mathrm{H}_{2} \mathrm{~S}$ levels are above $20 \mathrm{ppm}$, use a detector...don't assume! Always use a portable $\mathrm{H}_{2} \mathrm{~S}$ detector to monitor $\mathrm{H}_{2} \mathrm{~S}$ levels in a confined space. Low oxygen levels can be just as lethal as $\mathrm{H}_{2} \mathrm{~S}$. The ship's officers have oxygen meters to determine if a space has enough oxygen, but the oxygen meters do not measure $\mathrm{H}_{2} \mathrm{~S}$ levels. In some cases it is necessary to use both types of meters. $\mathrm{H}_{2} \mathrm{~S}$ levels may be safe at the entrance to a confined area but can change quickly to lethal levels, depending on the 
W.G. MILLS ET AL.

ODP TECHNICAL Note 33

source. $\mathrm{H}_{2} \mathrm{~S}$ is denser than air and will settle into low areas. Do not enter a confined space without using a BA to rescue someone who has passed out.

The following procedures describes implementing personnel rescue:

1. Put on a BA before proceeding to assist anyone affected by the gas.

2. Put on a safety belt with $50 \mathrm{ft}$ of tail line and obtain standby assistance before entering the area if the person is in a highconcentration area.

3. Utilize the buddy system when entering possible contaminated areas.

4. Move the victim to fresh air.

5. Administer resuscitation or oxygen as needed. Call the Ship's Doctor.

6. If the person is injured because of exposure to $\mathrm{H}_{2} \mathrm{~S}$, arrange for evacuation to a shore-based medical facility. 
W.G. MILLS ET AL.

ODP TECHNICAL Note 33

\section{REFERENCES}

Foss, G.N., and Julson, B.D., 1993. Revised hydrogen sulfide drilling contingency plan-JOIDES Resolution. ODP Tech. Note, 19.

Howard, S.P., and Reudelhuber, D.H., 1991. Hydrogen sulfide-high temperature drilling contingency plan. ODP Tech. Note, 16. 


\section{APPENDIX A \\ Location of Fixed Area Detectors}

Each detector station can support two sensors. The sensors should be mounted 6-12 in above the deck. Detector areas and number and position of fixed sensors follow:

Core Processing Area

Sensor 1: Below the sampling table next to the working half storage rack.

Sensor 2: Below the description table.

\section{Core Receiving Platform}

Sensor 1: Mount on handrail at the forward end of the platform next to the outdoor storage rack.

Sensor 2: Mount on the handrail at the midpoint of the platform.

\section{Core Entry}

Sensor 1: Mount at the base of the aluminum core rack.

Sensor 2: Mount beneath the splitting table.

\section{Core Catcher Bench}

Sensor 1: Mount on the handrail at the aft end of the core receiving platform.

Sensor 2: Mount beneath core catcher bench.

\section{Lower 'tween Deck Landing}

Sensor 1: Mount inside the lower 'tween core refrigerator at the base of the unistrut shelving.

\section{Hold Deck Landing}

Sensor 1: Mount inside the hold core refrigerator at the base of the unistrut shelving.

Sensor 2: Mount at the bottom of the stairwell.

\section{Fresh-Air Intake Plenum}

Sensor 1: Mount inside the fresh air intake plenum where the air enters the $\mathrm{A} / \mathrm{C}$ on the main deck.

Sensor 2: Mounted on the forward end of the core receiving platform.

\section{Rig Floor}

Sensor 1: Mount at the base of forward starboard tugger.

Sensor 2: Mount at the base of aft starboard tugger. 
W.G. MILLS ET AL.

ODP TECHNICAL Note 33

\title{
Warning Signs
}

Post warning signs at the entrance(s) to potential $\mathrm{H}_{2} \mathrm{~S}$ areas during operations at sites where $\mathrm{H}_{2} \mathrm{~S}$ may be encountered. Use the following text on the warning signs:

\author{
WARNING--HAZARDOUS AREA \\ HYDROGEN SULFIDE $\mathrm{H}_{2} \mathrm{~S}$ \\ UNAUTHORIZED PERSONNEL KEEP OUT \\ NO SMOKING
}

Warning signs are to be posted in the following areas:

- Rig floor,

- Core receiving platform,

- Core laboratory-in all areas where cores will be processed,

- Core storage reefer-including reefer entrance(s),

- Bottom of core laboratory stairwell- $\mathrm{H}_{2} \mathrm{~S}$ gas may accumulate in that area, and

- Living quarter exits that are entrances into designated $\mathrm{H}_{2} \mathrm{~S}$ danger areas-all deck levels.

\section{Wind Direction Indicators}

Wind socks are mounted on the following areas:

- Ship's bow,

- Crane no. 1,

- Crane no. 2, and

- Crane no. 3.

Bright color streamers are located in the following areas:

- Along the catwalk aft of crane no. 2,

- Under the rig floor on the mezzanine deck, and

- Along the port side of the core-receiving platform. 


\section{APPENDIX B}

\section{Origin of $\mathrm{H}_{2} \mathrm{~S}$}

\section{Formation and Consumption in Sediments}

In most cases where ODP is coring, $\mathrm{H}_{2} \mathrm{~S}$ forms as a byproduct of the degradation of organic matter. Because sulfate is plentiful in the ocean, sulfate reduction and, hence, hydrogen sulfide production is common in marine sediments.

Specifically, $\mathrm{H}_{2} \mathrm{~S}$ forms during sulfate reduction via the generalized formula

$$
2 \mathrm{CH}_{2} \mathrm{O}+\mathrm{SO}_{4}{ }^{2-} \rightarrow \mathrm{H}_{2} \mathrm{~S}+2 \mathrm{HCO}_{3}^{-}
$$

where

$$
\begin{aligned}
& \mathrm{CH}_{2} \mathrm{O}=\text { organic matter, } \\
& \mathrm{SO}_{4}{ }^{2-}=\text { sulfate, and } \\
& \mathrm{HCO}_{3}{ }^{-}=\text {bicarbonate or alkalinity. }
\end{aligned}
$$

Despite their common presence in marine sediments, $\mathrm{H}_{2} \mathrm{~S}$ concentrations do not usually reach very high levels. Relatively low concentrations of $\mathrm{H}_{2} \mathrm{~S}$ are maintained primarily because either the reactants (organic matter and/or sulfate) may be limited or iron combines with the sulfide to form iron sulfide minerals (e.g., pyrite).

The highest $\mathrm{H}_{2} \mathrm{~S}$ concentrations encountered during Deep Sea Drilling Project (DSDP)/ODP operations were located in the carbonate-rich sediments of the south Australian margin (Leg 182; 150,000 ppm in a single core). High sedimentation rates, low iron content, and sulfaterich pore fluids led to extensive production of $\mathrm{H}_{2} \mathrm{~S}$.

Typically, diffusion from overlying seawater is the main source of sulfate. However, on some continental margins brines may provide an additional source of sulfate for sulfate reduction and production of $\mathrm{H}_{2} \mathrm{~S}$.

In areas where overlying seawater is the main source of sulfate, $\mathrm{H}_{2} \mathrm{~S}$ concentrations will eventually decrease with depth. Even when there is high organic matter content, sulfate eventually becomes depleted with depth. Thus, $\mathrm{H}_{2} \mathrm{~S}$ may be encountered over several cores but, like sulfate, $\mathrm{H}_{2} \mathrm{~S}$ should also decline with depth.

\section{Environments}

Typical environments where $\mathrm{H}_{2} \mathrm{~S}$ may be present are terrigenous continental margins, carbonate-rich continental margins or carbonate banks, gas hydrate sediments, and hydrothermal systems.

$\mathrm{H}_{2} \mathrm{~S}$ may be present in terrigenous continental margin environments, especially where coastal upwelling results in sediments with high organic matter content. Typically in this setting, the sedimentary components often provide plenty of available iron, resulting in the removal of $\mathrm{H}_{2} \mathrm{~S}$ via iron sulfide precipitation.

Slopes of carbonate-rich continental margins or carbonate banks with high sedimentation rates may be a source of $\mathrm{H}_{2} \mathrm{~S}$. Although carbonate-rich sediments are typically not rich in organic matter, the slopes can be characterized by high sedimentation rates. High accumulation rates bury organic matter, creating an increased potential for organic matter availability for sulfate reduction. Carbonate-rich sedi- 
W.G. MILLS ET AL.

ODP TECHNICAL Note 33

ments also have low iron contents, so $\mathrm{H}_{2} \mathrm{~S}$ is rarely quantitatively precipitated as iron sulfides.

Another potential point source of $\mathrm{H}_{2} \mathrm{~S}$ on continental margins is gas hydrates (clathrates). Although most natural marine hydrates are dominated by methane, $\mathrm{H}_{2} \mathrm{~S}$-methane hydrates have been encountered (e.g., Cascadia margin, Legs 146 and 182). Incorporation of $\mathrm{H}_{2} \mathrm{~S}$ into the hydrate structure shifts the hydrate stability field; hence, $\mathrm{H}_{2} \mathrm{~S}$-rich hydrates are found at shallower depths than methane hydrates.

$\mathrm{H}_{2} \mathrm{~S}$ may be encountered in hydrothermal systems (e.g., massive sulfide deposits). Consequently, appropriate precautions should be in place when recovering such fluids or coring sediments whose pore fluids may contain a hydrothermal component. 
W.G. MILLS ET AL.

ODP TECHNICAL Note 33

\section{APPENDIX C \\ Properties of $\mathrm{H}_{2} \mathrm{~S}$}

Hydrogen sulfide is colorless, transparent, and flammable, smells like "rotten eggs" at very low concentrations, and is denser than air and thus may accumulate in low places.

The slightest presence of $\mathrm{H}_{2} \mathrm{~S}$ in the air is normally detectable by its characteristic "rotten-egg" odor; however, it is dangerous to rely on odor as a means of detecting life-threatening concentrations because the sense of smell is lost rapidly, allowing lethal concentrations to accumulate without warning.

Table AT1 describes the poisonous nature of hydrogen sulfide.

Table AT1. Effects of hydrogen sulfide.

\begin{tabular}{cccl}
\hline \multicolumn{3}{c}{ Concentration of $\mathrm{H}_{2} \mathrm{~S}$} & \\
\cline { 1 - 2 }$(\%)$ & $(\mathrm{ppm})$ & $\left(\mathrm{g} / 100 \mathrm{ft}^{3}\right)$ & \\
\hline 0.001 & 10 & 0.65 & Obvious and unpleasant odor; safe for $8 \mathrm{hr}$ \\
0.002 & 20 & 1.3 & Safe for 4 hr exposure \\
0.01 & 100 & 6.48 & Kills sense of smell in 3-15 min; may sting eyes and throat \\
0.02 & 200 & 12.96 & Kills sense of smell; stings eyes and throat \\
0.05 & 500 & 32.96 & Dizziness; breathing ceases in minutes; need prompt artificial respiration \\
0.07 & 700 & 45.26 & Unconscious quickly; death will result if not rescued promptly \\
0.1 & 1000 & 64.8 & Unconscious immediately, followed by death within minutes \\
\hline
\end{tabular}




\section{APPENDIX D \\ Other Hazardous Gases}

\section{Carbon Dioxide}

Carbon dioxide $\left(\mathrm{CO}_{2}\right)$ is commonly found dissolved in hydrothermal fluids and could be released from pore water when cores are recovered. $\mathrm{CO}_{2}$ is usually considered inert and is heavier than air (1.5 times), concentrating in low areas of quiet air.

Carbon dioxide gas is toxic in higher concentrations but much less so than $\mathrm{H}_{2} \mathrm{~S}$ (see Table AT2). The threshold limit of $\mathrm{CO}_{2}$ is $5000 \mathrm{ppm}$. Short-term exposure to 50,000 ppm (5\%) is reasonable. This gas is colorless and odorless and can be tolerated in relatively high concentration.

Air containing $5 \% \mathrm{CO}_{2}$ will cause disorientation in a few minutes. Continued exposure to $\mathrm{CO}_{2}$ after being affected will cause convulsions, coma, and respiratory failure. If a massive flow of $\mathrm{CO}_{2}$ from the well bore should occur (highly unlikely), the principal danger would be from asphyxiation due to lack of air.

Using a BA will provide adequate oxygen until the emergency can be controlled.

Table AT2. Chemical vapor toxicity.

\begin{tabular}{llcccr}
\hline Common name & $\begin{array}{c}\text { Chemical } \\
\text { formula }\end{array}$ & $\begin{array}{c}\text { Specific } \\
\text { gravity } \\
(\text { air }=1)\end{array}$ & $\begin{array}{c}\text { Threshold* } \\
\text { limit } \\
(\mathrm{ppm})\end{array}$ & $\begin{array}{c}\text { Hazardous } \\
\text { limit } \\
(\mathrm{ppm} / \mathrm{hr})\end{array}$ & $\begin{array}{c}\text { Lethal } \\
\text { concentration } \\
\text { (ppm) }\end{array}$ \\
\hline $\begin{array}{l}\text { Hydrogen cyanide } \\
\text { Hydrogen sulfide }\end{array}$ & $\mathrm{HCN}$ & 0.94 & 10 & 150 & 300 \\
Sulfur dioxide & $\mathrm{H}_{2} \mathrm{~S}$ & 1.18 & 10 & 250 & 600 \\
Chlorine & $\mathrm{SO}_{2}$ & 2.21 & 2 & - & 1,000 \\
Carbon monoxide & $\mathrm{Cl}_{2}$ & 2.45 & 1 & 4 & 1,000 \\
Carbon dioxide & $\mathrm{CO}_{2}$ & 0.97 & 50 & 400 & 1,000 \\
Methane & $\mathrm{CO}_{2}$ & 1.52 & 5,000 & $5 \%$ & 100,000 \\
& $\mathrm{CH}_{4}$ & 0.55 & 90,000 & $>5 \%$ in air & - \\
\hline
\end{tabular}

Notes: * $=$ concentration at which it is believed that all workers may repeatedly be exposed, 8 $\mathrm{hr} /$ day, every day, without adverse effect. $\dagger=$ concentration that may cause death. $\ddagger=$ concentration that will cause death with short-term exposure.

\section{Hydrocarbon Gas}

Hydrocarbon compounds are known to be present in sediments and potentially in hydrothermal fluids. These hydrocarbons are primarily in the form of methane gas, but some heavier gases and even liquids are possible.

The toxicity of methane is very low (see Table AT2), but it is often a "carrier" of $\mathrm{H}_{2} \mathrm{~S}$. Because hydrocarbon gas is lighter than air, it does not tend to settle and is easily dispersed. The major threat from natural gas is its extreme flammability and explosivity. Hydrocarbon liquids may be carcinogenic, so common sense should be used in handling them if they are encountered.

The blowout control measures specified in this document can be use to control hydrocarbon gas as well as $\mathrm{H}_{2} \mathrm{~S}$. 
W.G. MILLS ET AL.

Radon

The barite precipitated in seafloor rocks and sediments by hydrothermal activity has been found to contain measurable amounts of radioactive radium-226, which is chemically similar to barium. Small amounts of radon may also be present in the pore water.

The radium emits very small amounts of radon-222 gas through radioactive decay, which also is radioactive. The radiation is in the form of alpha particles, which have extremely limited ability to penetrate tissue. Thus, the principal danger comes from inhaling or ingesting the radioactive material. Furthermore, the levels of radioactivity are extremely low-on the nannocurie scale.

ODP has investigated the potential effect of that radiation on health and safety on board the ship. Nevertheless, cores will be monitored for radioactivity if radioactive material is present.

The following precautions are to be taken if radon is encountered:

- Use extra ventilation around cores (as with $\mathrm{H}_{2} \mathrm{~S}$ ) before packing and when D-tubes are opened.

- Seal D-tubes to contain gas and/or ventilate storage areas.

- Avoid eating and drinking in the immediate area of the cores.

- Wash hands thoroughly after handling barite-rich cores or samples.

\section{Sulfur Dioxide}

Sulfur dioxide is produced during the burning of $\mathrm{H}_{2} \mathrm{~S}$. Sulfur dioxide is colorless, transparent, nonflammable, heavier than air, but will be picked up by a breeze and carried downwind at elevated temperatures, and extremely irritating to the eyes and mucous membranes of the upper respiratory tract.

Table AT3 indicates the toxic nature of the gas.

Table AT3. Effects of sulfur dioxide.

\begin{tabular}{|c|c|c|}
\hline \multicolumn{2}{|c|}{ Concentration of $\mathrm{SO}_{2}$} & \multirow[b]{2}{*}{ Effect } \\
\hline$(\%)$ & $(\mathrm{ppm})$ & \\
\hline 0.0002 & 2 & Safe for $8 \mathrm{hr}$ \\
\hline 0.005 & $3-5$ & Pungent odor; normally a person can detect $\mathrm{SO}_{2}$ in this range \\
\hline 0.0012 & 12 & Throat irritation, coughing, chest constriction, eyes tear and burn \\
\hline 0.015 & 150 & So irritating that it can only be endured for a few minutes \\
\hline 0.05 & 500 & Causes a sense of suffocation, even with first breath. \\
\hline
\end{tabular}




\section{APPENDIX E}

\section{Facial Hair Waiver}

\section{Waiver: Hydrogen Sulfide Exposure-FACIAL HAIR}

Conditions may develop that require air breathing masks/respirators to be worn by personnel working in designated hazardous areas. A proper seal between the surface of a respirator face piece and the wearer's skin is imperative. Facial hair, such as beards, sideburns, moustaches, and even a few days' growth of stubble will prevent a good seal. Facial hair results in the respirator permitting negative air pressure inside the face piece during inhalation and causing excessive penetration by an air contaminant.

If the individual elects not to shave facial hair, he must sign the statement provided below.

My signature below (with witness) indicates that I have been informed of the dangers associated with using a breathing apparatus that might not seal properly because of interfering facial hair, and I choose not to hold the Ocean Drilling Program-Texas A\&M University, Texas A\&M Research Foundation, National Science Foundation, or the owners of the $R / V$ JOIDES Resolution responsible for any accidents, illness, or medical problems that might occur if it becomes necessary for me to use a breathing apparatus during an $\mathrm{H}_{2} \mathrm{~S}$ emergency.

Signature:

Witness:
Date:

Date: 


\section{APPENDIX F}

\section{Perforated Ear Drum Waiver}

\section{Waiver: Hydrogen Sulfide Exposure-Perforated Ear Drum}

Due to the nature of operations on Leg __, participants face potential exposure to hydrogen sulfide $\left(\mathrm{H}_{2} \mathrm{~S}\right)$ gas. Situations may develop that require air-breathing masks/respirators to be worn by personnel working in designated hazardous areas. Since the protective breathing apparatus does not cover the ears, $\mathrm{H}_{2} \mathrm{~S}$ may enter the body through a perforated or punctured eardrum.

If an individual suspects or has been diagnosed to have a punctured/perforated eardrum but elects to participate on ODP Leg he or she must sign the statement provided below.

My signature below (with witness) indicates that I have been informed of the dangers associated with hydrogen sulfide $\left(\mathrm{H}_{2} \mathrm{~S}\right)$ exposure when a perforated or punctured eardrum condition exists. I choose not to hold the Ocean Drilling Program-Texas A\&M University, Texas A\&M Research Foundation, National Science Foundation, or the owners of the $R / V$ JOIDES Resolution responsible for any accidents, illness, or medical problems that might occur as a result of $\mathrm{H}_{2} \mathrm{~S}$ exposure via a punctured or perforated eardrum.

Signature:

Date:

Witness:

Date: 


\title{
PUBLISHER'S NOTES
}

Material in this publication may be copied without restraint for library, abstract service, educational, or personal research purposes; however, this source should be appropriately acknowledged.

Mills, W.G., Malone, M.J., and Graber, K., 2005. Hydrogen sulfide drilling contingency plan. ODP Tech. Note, 33 [Online]. Available from World Wide Web: <http://www-odp.tamu.edu/publications/tnotes/tn33/ INDEX.HTM>. [Cited YYYY-MM-DD]

Distribution: Electronic copies of this publication may be obtained from the ODP Publications homepage on the World Wide Web at http://www-odp.tamu.edu/publications.

This publication was prepared by the Ocean Drilling Program, Texas A\&M University, as an account of work performed under the international Ocean Drilling Program, which is managed by Joint Oceanographic Institutions, Inc., under contract with the National Science Foundation. Funding for the program is provided by the following agencies:

\author{
Australia/Canada/Chinese Taipei/Korea Consortium for Ocean Drilling \\ Deutsche Forschungsgemeinschaft (Federal Republic of Germany) \\ European Science Foundation Consortium for Ocean Drilling (Belgium, Denmark, Finland, Iceland, \\ Ireland, Italy, The Netherlands, Norway, Portugal, Spain, Sweden, and Switzerland) \\ Institut National des Sciences de l'Univers-Centre National de la Recherche Scientifique (INSU-CNRS; \\ France) \\ Marine High-Technology Bureau of the State Science and Technology Commission of the People's \\ Republic of China \\ Ocean Research Institute of the University of Tokyo (Japan) \\ National Science Foundation (United States) \\ Natural Environment Research Council (United Kingdom)
}

\section{DISCLAIMER}

Any opinions, findings, and conclusions or recommendations expressed in this publication are those of the author(s) and do not necessarily reflect the views of the National Science Foundation, the participating agencies, Joint Oceanographic Institutions, Inc., Texas A\&M University, or Texas A\&M Research Foundation. 
W.G. MILLS ET AL.

ODP TECHNICAL Note 33

Figure F1. Core on splitting table.

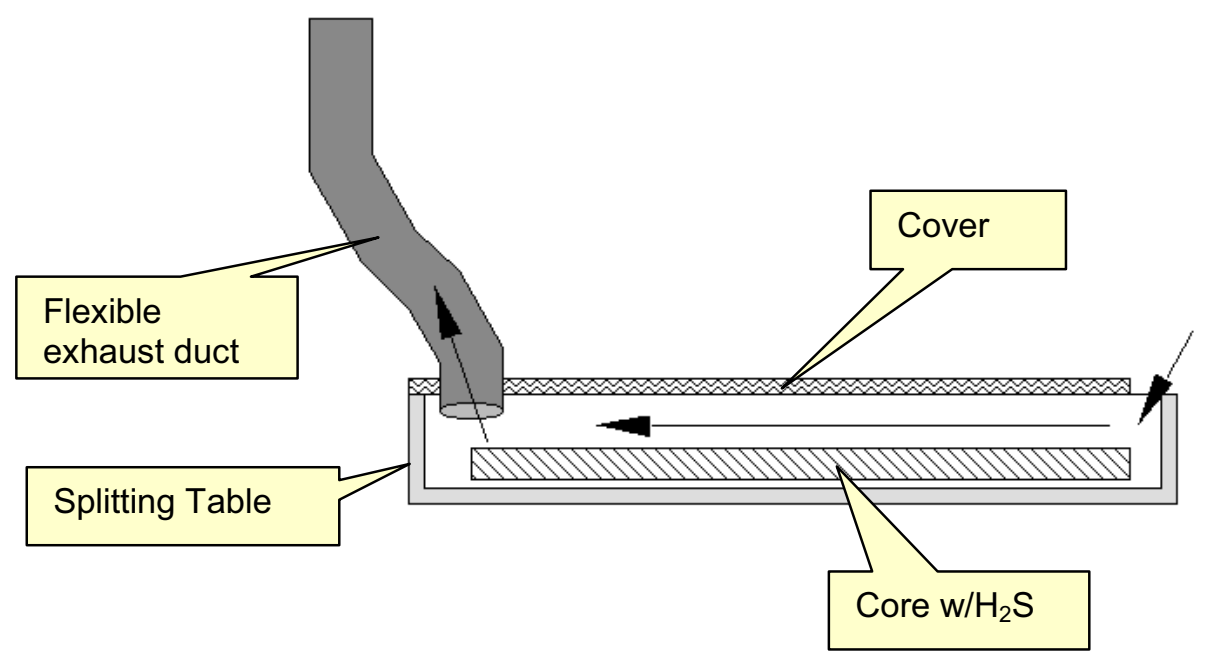

